\title{
Cerebriform intradermal nevus - A rare clinical entity presenting as cutis verticis gyrata
}

\section{Chandramohan Kudligi, Vidya Kuntoji, Pradeep Vittal Bhagwat, Chovatiya Keyur Mohanbhai, Safura Tazeen}

Department of Dermatology and Venereology, Karnataka Institute of Medical Sciences, Hubli, Karnataka, India

Corresponding author: Dr. Vidya Kuntoji, E-mail: drvidyakuntoji@gmail.com

\begin{abstract}
Cutis verticis gyrata is a rare skin condition characterized by convoluted folds and furrows formed from thickened skin resembling a cerebriform pattern. The condition is usually but not exclusively limited to the scalp. It may present in either primary form with or without any associations or in secondary forms with a wide variety of causes. Cerebriform intradermal nevus is one such rare cause of this unusual condition. We present a case of cerebriform intradermal nevus involving scalp and the upper half of left cheek which had both cerebriform appearances as well as the smooth surface.
\end{abstract}

Key words: Cutis verticis gyrata; Intradermal; Nevus; Scalp

\section{INTRODUCTION}

Cutis verticis gyrata is a rare disorder of the scalp, characterized by the formation of furrows and folds resembling the surface of the brain [1]. Though it is mainly seen on the scalp, it can also be located on the neck, legs, buttocks, scrotum or back [2]. It can be classified into primary and secondary types. The former can be either essential or non-essential depending on the presence of associations like cerebral palsy, epilepsy, seizure, mental retardation and the latter is caused by a wide variety of underlying conditions. Cerebriform intradermal nevus, a rare condition of the scalp is one such cause of cutis verticis gyrate $[3,4]$.

\section{CASE REPORT}

A 28-year-old female presented to our Dermatology outpatient department with a swelling/mass on one-half of the scalp which was present since birth and was gradually progressive. It was associated with occasional mild itching. The patient also gave the history of hair loss/alopecia in the area of swelling since birth. She was born out of a non- consanguineous marriage with an uneventful birth history. The family history was insignificant and her elder sister was normal. There was no history of epilepsy or mental retardation. On cutaneous examination, there was a $25 \times 15 \mathrm{~cm}$ mass, which was confined to left half of the scalp involving left temporal and left occipital regions and a part of it was extending to upper half of left cheek abutting the left eye (Fig. 1). It was non-tender and soft to firm in consistency. There were deep folds in the lowermost part of the swelling in parietal and occipital regions. There were mild scaling and atrophy of skin along with alopecia over the swelling. The skin over the swelling was not pinchable.

Routine blood investigations were normal. Ophthalmological examination was normal. CT scan of the head showed no bony or intracranial abnormalities. Histopathological examination of punch biopsy specimens revealed nests of nevus cells containing varying amounts of melanin in the papillary and reticular dermis without any cellular atypia (Figs. 2 and 3). The diagnosis was consistent with Cerebriform intradermal nevus.

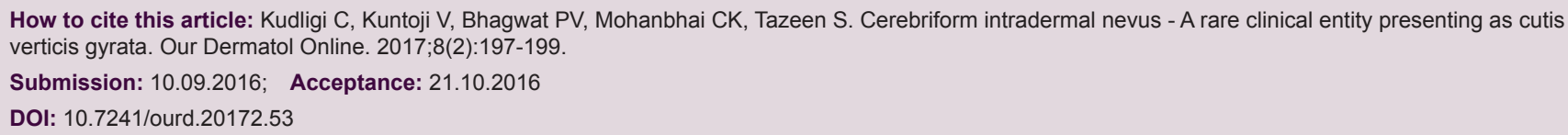




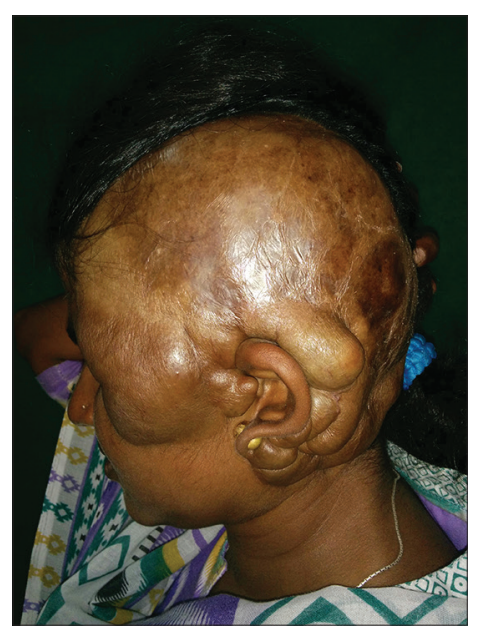

Figure 1: Mass having both convoluted and smooth surface involving left half of the scalp.

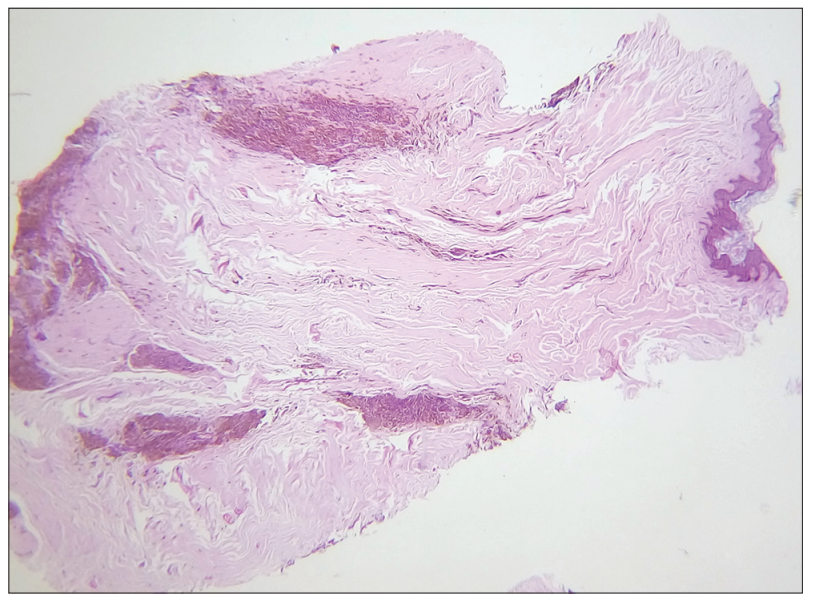

Figure 2: Skin biopsy involving nests of naevus cells surrounded by thick collagen bundles in the dermis (H\&E: X10).

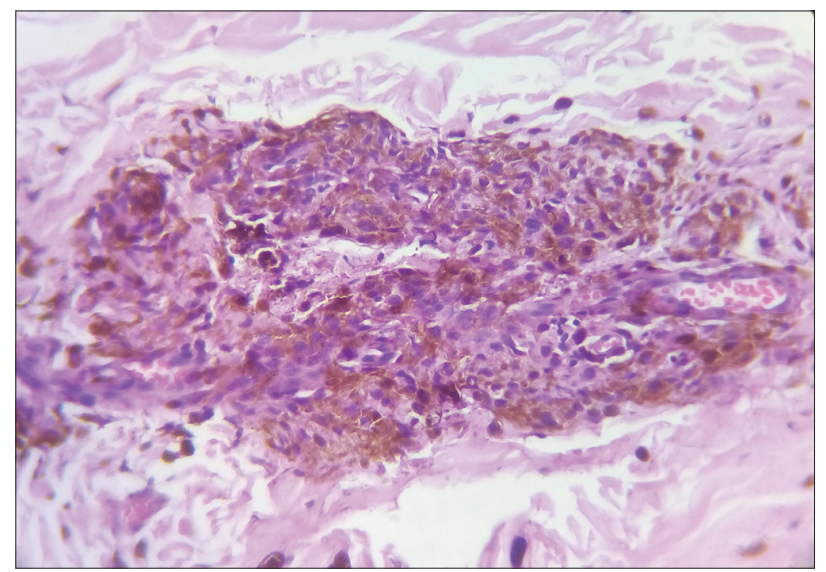

Figure 3: Skin biopsy showing melanin pigment and naevus cells (H\&E: X40).

\section{DISCUSSION}

Cutis verticis gyrata is an abnormality of the scalp characterized by the formation of furrows and folds resembling the surface of the brain. It is classified as primary and secondary types. The primary form is further classified as essential and non-essential types. The primary essential form has no other associations with it whereas the primary non-essential type is often associated with seizure, mental retardation, cataracts and optic atrophy. The secondary form is caused due to underlying diseases like acromegaly, amyloidosis, cylindroma, focal mucinosis, myxedema, melanocytic nevi, neurofibroma, pachydermoperiostosis, tuberous sclerosis, turner syndrome and so on [5]. Cerebriform intradermal nevus is one such rare cause of secondary cutis verticis gyrata which confers a convoluted appearance.

It is a nodular nevus cerebriform on its surface and is present in the dermis on histopathology [6,7]. Hammond and Ransom first described a Cerebriform nevus resembling cutis verticis gyrata in 1937 [8]. Presenting at birth or early life, it is attributed that females are more likely to develop this condition [7]. It can be either asymptomatic or can be associated with progressive alopecia, pruritus, tenderness, burning, bleeding and fetid odor $[9,10]$. Our patient was female and had mild occasional itching and also alopecia confined to the nevus since birth. Unlike the reports in the literature $[6,11,12]$, our patient had limited convolutions with a major part of the surface of the scalp being plain. And its extension on the face involving half of the upper cheek was unusual in this case. Although there is varied opinion regarding the relation of giant melanocytic naevus with the cerebral intradermal nevus, the possibility of giant melanocytic naevus in our case was ruled out by the absence of hairy and junctional activity [7,13]. Our patient was normal in intellect and she did not have any other abnormalities. But it is important to know that cerebriform intradermal nevus is associated with the risk of malignant melanoma [14,15]. The life-time incidence of melanoma arising in a giant nevus or in smaller nevi is $6.3 \%$ and $12 \%$ [9].

\section{CONCLUSION}

Cerebriform intradermal nevus is one of the rare causes of Cutis verticis gyrata. Apart from its cerebriform appearance, the major part of the surface of scalp was smooth and also it had an extension over the face. Since it carries the risk of malignant melanoma, there lies the importance of early diagnosis, regular follow-up and management of this rare condition. 


\section{www.odermatol.com}

\section{REFERENCES}

1. Woollons A, Darley CR, Lee PJ, Brenton DP, Sonksen PH, Black MM. Cutis verticis gyrata of the scalp in a patient with autosomal dominant insulin resistance syndrome. Clin Exp Dermatol. 2000;25:125-8.

2. Quaedvlieg PJ, Frank J, Vermeulen AH, Toonstra J, van Neer FJ. Giant ceribriform intradermal nevus on the back of a newborn. Pediatr Dermatol. 2008;25:43-6.

3. Schenato LK, Gil T, Carvalho LA, Ricachnevsky N, Sanseverino A, Halpern R. Essential primary cutis verticis gyrata. J Pediatr (Rio J). 2002;78:75-80.

4. Ghosh SK, Bandyopadhyay D, Ghoshal L, Sarkar S. Lobulated mass on the back of the scalp. Indian J Dermatol Venereol Leprol. 2012;78:225-7.

5. Sarkar S, Roychoudhury S, Shrimal A, Das K. Cerebriform intradermal nevus presenting as cutis verticis gyrata with multiple cellular blue nevus over the body: A rare occurrence. Indian Dermatol Online J. 2014;5:34-7.

6. Tabata H, Yamakage A, Yamazaki S. Cerebriform intradermal nevus. Int J Dermatol. 1995;34:634.

7. Alcántara González J, Truchuelo Díez MT, Carrillo Gijon R, Martin Diaz RM, Jaen Olasolo P. Letter: Cerebriform intradermal nevus presenting as secondary cutis verticis gyrates. Dermatol Online J. 2010;16:14.

8. Von Geest AJ, Berretty PJ, Klinkhamer PJ, Neumann HA. Cerebriform intradermal naevus (a rare form of secondary cutis verticis gyrata). J Eur Acad Dermatol Venereol. 2002;16:529-31.

9. Phiske M.Cerebriform intradermal nevus: A rare entity and its associations. Indian Dermatol Online J. 2014;5:115-6.

10. Orkin M, Frichot III BC, Zelickson AS. Cerebriform intradermal nevus. A cause of cutis verticis gyrata. Arch Dermatol. 1974;110:575-82

11. Ghosh SK, Bandyopadhyay D, Ghoshal L, Sarkar S. Lobulated mass on the back of the scalp. Indian J Dermatol Venereol Leprol. 2012;78:225-7.

12. Filho AB, Darrigo LG, Avelleira JCR, Kac BK, Azulay DR. Cerebriform Intradermal Nevus as a cause of Cutis verticis gyrata. Rev Assoc Med Bras. 2010;56:639-41.

13. Yazici AC, Ikizoglu G, Baz K, Polat A, Ustunsoy D. Cerebriform intradermal nevus. Pediatr Dermatol. 2007;24:141-3.

14. Hayashi Y, Tanioka M, Taki R, Sawabe K, Kore-Eda S, Utani A, et al. Malignant melanoma derived from cerebriform intradermal naevus. Clin Exp Dermatol. 2009;34:e840-2.

15. Tagore KR, Ramineni AK. A case of cutis verticis gyrata secondary to giant cerebriform intradermal nevus. Indian J Pathol Microbiol. 2011;54:624-5

Copyright by Chandramohan Kudligi, et al. This is an open-access article distributed under the terms of the Creative Commons Attribution License, which permits unrestricted use, distribution, and reproduction in any medium, provided the original author and source are credited.

Source of Support: Nil, Conflict of Interest: None declared. 